\title{
Effects of JAM-A rs790056 and LFA-1 rs8058823 Variations on Kidney Cancer
}

\author{
Halime Hanım Pençe1 (D), Burcu Çaykara² (1), Sadrettin Pençe² (D), Bengü Tokat² (D), Alper Ötünçtemur ${ }^{3}$ (D) \\ 1Department of Medical Biochemistry, University of Health Sciences School of Medicine, İstanbul, Turkey \\ ${ }^{2}$ Department of Molecular Medicine, İstanbul University Aziz Sancar Institute of Experimental Medicine (ASDETAE), İstanbul, Turkey \\ ${ }^{3}$ Department of Urology, University of Health Sciences Okmeydanı Training and Research Hospital, İstanbul, Turkey
}

Cite this article as: Pençe HH, Çaykara B, Pençe S, Tokat B, Ötünçtemur A. Effects of JAM-A rs790056 and LFA-1 rs8058823 Variations on Kidney Cancer. JAREM 2019; 9(Supplement 1): S41-4.

\begin{abstract}
Objective: Kidney cancer is a type of cancer that includes different histology subgroups, and the number of kidney cancer cases is expected to increase. It has been found that the junctional adhesion molecule A (JAM-A) as a transmembrane glycoprotein is associated with cancer characteristics such as invasion, metastasis, and poor prognosis. Therefore, we aimed to investigate the effect of gene variations in JAM-A and its ligand lymphocyte function-related antigen-1 (LFA-1) on kidney cancer.

Methods: DNA was isolated from 50 renal tumors and 50 healthy peripheral tissues. Gene variants of DNA samples were analyzed using the polymerase chain reaction and restriction fragment length polymorphism methods. The Statistical Package for Social Sciences version 22.0 (IBM Corp., Armonk, NY, USA) was used for statistical analysis, and $p<0.05$ was accepted as statistically significant.

Results: Genotype and allele distributions of JAM-A rs790056 and LFA-1 rs8058823 were similar in tumor and healthy peripheral tissues ( $p>0.05$ ).

Conclusion: In our study, it was observed that JAM-A rs790056 and LFA-1 rs8058823 had no effect on kidney cancer.

Keywords: JAM-A, rs790056, LFA-1, rs8058823, kidney cancer
\end{abstract}

\section{INTRODUCTION}

Kidney cancer includes types of cancer with a different histology and different response to treatment. Mutations in known kidney cancer genes, such as the $\mathrm{VHL}, \mathrm{MET}$, and $\mathrm{FH}$, cause irregularities in the metabolic pathways involved in oxygen, iron, energy, or nutrient sensing (1). The incidence of kidney cancer is observed at higher rates in well-developed countries such as Europe and North America. Kidney cancer is the $12^{\text {th }}$ most common cancer in the world and $9^{\text {th }}$ in Europe. It has been predicted that by 2020, kidney cancer will increase by 22\%, compared to 2015 (2).

A study by Gutwein et al. (3) published in 2009 reported that the downregulation of junctional adhesion molecule A (JAM-A or F11R) is an early stage in the development of kidney cancer and that it increases the migration of these cells. It was found that the JAM-A expression in mononuclear cells was positively correlated with high-grade glioma, and it was suggested that JAM-A can act as a biomarker in glioblastoma for patient survival (4). Circulating soluble JAM-A (sJAM-A) levels were also found to be significantly increased in multiple myeloma pa- tients (5). JAM-A, a Type I transmembrane glycoprotein, was found to be associated with cell-cell adhesion, platelet activation, leukocyte migration, invasion, metastasis, and poor prognosis (5). Furthermore, since JAM-A is normally expressed in kidney tissue, it was suggested that JAM-A may be necessary to maintain the physiological concentrations of ions, solutes, and water (6). JAM-A is the ligand of the beta 2 ( $\beta 2)$ integrin lymphocyte function-associated antigen 1 (LFA-1 or ITGB2) to guide and control transmigration during leukocyte recruitment (7). In a recent study, signal pathway analyses were performed to identify potential genes and pathways associated with carcinogenesis in clear cell renal cell cancer (ccRCC). The LFA-1 gene was found upregulated in the ccRCC samples, and the protein-protein interaction showed that the LFA-1 gene could contribute to the carcinogenesis of kidney cancer (8). Furthermore, LFA-1 was found to be correlated with poor survival in renal cell cancer (9).

Thus, we aimed to reveal the effects of JAM-A (rs790056) and LFA-1 (rs8058823) variations on kidney cancer. 


\section{METHODS}

We studied 50 patients diagnosed with kidney cancer, a total of 100 matched tumor, and healthy peripheral kidney tissues samples. We excluded other urological cancer types and the non-matched tumor-control tissues. The Ethical Committee of the İstanbul University School of Medicine approved our study protocol (No: 2016/535), and informed consent was obtained from the patients. DNA was isolated from 50 renal tumors and 50 healthy peripheral tissues with the QIAzol Lysis Reagent (QIAGEN). The variations of JAM-A gene rs790056 (in intron 6, T>C) and LFA-1 gene rs8058823 (in 3'-untranslated region, $A>G$ ) were obtained with the polymerase chain reaction and restriction fragment length polymorphism (PCR-RFLP) methods described by Tokat et al. (10).

\section{Statistical Analysis}

The Statistical Package for Social Sciences software for Windows, version 22.0 (IBM Corp.; Armonk, NY, USA), was used for statistical analysis. A Chi-square test was used to detect the genotypes and Hardy-Weinberg equilibrium (HWE) in the groups. The Kolmogorov-Smirnov test was used for the distribution of data. Pearson's correlation and Spearman's rho test were performed to show the relation between genotypes and other values. $A p<0.05$ was considered to be statistically significant.

\section{RESULTS}

The mean age and tumor diameter were $59.3 \pm 13.436$ and $6.04 \pm 2.51$ in patients with kidney cancer, respectively. The variations of JAM-A rs790056 and LFA-1 rs8058823 were in HardyWeinberg equilibrium ( $p>0.05$ ) (Table 1).

The allele and genotype distributions of the JAM-A rs790056 T>C variation were similar in the tumor and control group $(p>0.05)$. No risk was found for the $\mathrm{CC}$ and $\mathrm{TC}+\mathrm{CC}$ genotype carriers compared to the carriers of TT $(0.931$ and 0.85 , respectively) ( $>>0.05)$ (Table 2). The LFA-1 rs8058823 A>G variation distributions of allele and genotypes were found to be similar in tumor and con-

trol group ( $p>0.05$ ). The carriers of $G G$ and $A G+G G$ genotypes were compared to TT carriers, and no statistical risk was found between them (0.938 and 0.844, respectively) ( $p>0.05)$ (Table 3).

The Kolmogorov-Smirnov test showed that age was normally distributed, while the tumor diameter was non-normally distributed. Thus, the correlation for age was tested using Pearson's correlation test, and Spearman's rho test was used for the tumor diameter in the JAM-A gene rs790056 and LFA-1 gene rs8058823 variations. There was no correlation found between the genotypes and these values (data not shown).

\section{DISCUSSION}

We conducted a case control study including 50 patients diagnosed with kidney cancer, a total of 100 matched tumor and healthy kidney tissue samples. The allele and genotype distributions for the JAM-A rs790056 and LFA-1 rs8058823 variation were found to be similar in the tumor and control groups $(p>0.05)$. There was no risk found between the normal and mutant genotypes ( $p>0.05$ ) for kidney cancer.

JAM-A, a transmembrane protein of the immunoglobulin (lg) superfamily, has been reported to be involved in carcinogenesis via signaling pathways such as the TGF- $\beta 1$ signaling in various cancers (11). Furthermore, the upregulation of JAM-A was found to be associated with the TNM stage, lymph node metastasis, and decreased overall survival in non-small cell lung cancer (12). JAM-A interacts with LFA-1, a heterodimeric transmembrane glycoprotein, in the transendothelial migration of neutrophils and mononuclear cells (10). Tomita et al. (13) found that the number of ICAM-I, an LFA-1 receptor, -positive cells was significantly correlated with the degree of mononuclear cell infiltration involving T lymphocytes and macrophage carrying the LFA-1 molecule in renal cell cancer. Because these genes play a role in carcinogenesis, and limited study data involving variations of these genes for cancer were found in the literature, we aimed to show the effects of these gene variations on kidney cancer.

Table 1. The Hardy-Weinberg equilibrium for the variations of the JAM-A gene rs790056 (in Intron $6, T>C$ ) and LFA-1 gene rs8058823 (in $3^{\prime}$-untranslated region, $A>G$ )

\begin{tabular}{|c|c|c|c|c|c|}
\hline \multicolumn{6}{|c|}{ JAM-A Gene rs790056 Variation } \\
\hline Groups & Genotypes & Observed (n) & Expected (n) & Chi-squared & $p$ \\
\hline \multirow[t]{2}{*}{ Tumor } & $\mathrm{TT}$ & 29 & 28 & \multirow[t]{4}{*}{0.162} & \multirow[t]{4}{*}{0.687} \\
\hline & $\mathrm{TC}+\mathrm{CC}$ & 21 & 22 & & \\
\hline \multirow[t]{2}{*}{ Control } & $\mathrm{TT}$ & 27 & 28 & & \\
\hline & $\mathrm{TC}+\mathrm{CC}$ & 23 & 22 & & \\
\hline \multicolumn{6}{|c|}{ LFA-1 Gene rs8058823 Variation } \\
\hline Groups & Genotypes & Observed (n) & Expected (n) & Chi-squared & $p$ \\
\hline \multirow[t]{2}{*}{ Tumor } & AA & 32 & 31 & \multirow[t]{4}{*}{0.17} & \multirow[t]{4}{*}{0.68} \\
\hline & $A G+G G$ & 18 & 19 & & \\
\hline \multirow[t]{2}{*}{ Control } & AA & 30 & 31 & & \\
\hline & $A G+G G$ & 20 & 19 & & \\
\hline
\end{tabular}


Table 2. Relative risk, allele, and genotype distributions of JAM-A rs790056

\begin{tabular}{|l|c|c|c|c|}
\hline JAM-A rs790056 & Tumor $(\mathbf{n})(\%)$ & Control $(\mathbf{n})(\%)$ & OR (95\%Cl) & P \\
\hline T & $73(73)$ & $71(71)$ & reference & \\
\hline C & $27(27)$ & $29(29)$ & $0.906(0.488-1.679)$ & 0.753 \\
\hline TT & $29(58)$ & $27(54)$ & reference & \\
\hline TC & $15(30)$ & $17(34)$ & $0.822(0.344-1.961)$ & 0.658 \\
\hline CC & $6(12)$ & $6(12)$ & $0.931(0.268-3.240)$ & 0.911 \\
\hline TC+CC & $21(42)$ & $23(46)$ & $0.85(0.386-1.874)$ & 0.687 \\
\hline n: number & & & & \\
\hline
\end{tabular}

Table 3. Relative risk, allele, and genotype distributions of LFA-1 rs8058823

\begin{tabular}{|l|c|c|c|c|}
\hline LFA-1 rs8058823 & Tumor $(\mathbf{n})(\%)$ & Control $(\mathbf{n})(\%)$ & OR (95\%Cl) & $p$ \\
\hline A & $79(79)$ & $77(77)$ & reference & \\
\hline G & $21(21)$ & $23(23)$ & $0.89(0.456-1.739)$ & 0.733 \\
\hline AA & $32(64)$ & $30(60)$ & reference & \\
\hline AG & $15(30)$ & $17(34)$ & $0.827(0.352-1.944)$ & 0.663 \\
\hline GG & $3(6)$ & $3(6)$ & $0.938(0.175-5.01)$ & 0.94 \\
\hline n: number & $18(36)$ & $20(40)$ & $0.844(0.376-1.894)$ & 0.68 \\
\hline
\end{tabular}

Tokat et al. (10) showed that the frequency of JAM-A rs790056 major allele and genotype were higher in coronary heart disease (CHD), and the major TT genotype was identified as the CHD risk factor. The frequencies of the major TT genotype and allele were not found to be statistically different in breast cancer. Furthermore, the heterozygote TC genotype and minor CC genotype were also found similar in patients with breast cancer and control groups ( $p>0.05$ ) (14). In our study, we did not observe any differences between the study group for the frequencies of genotypes and alleles.

The frequency of the AA genotype of LFA-1 rs8058823 was found to be higher, while for the AG genotype, it was found to be lower in CHD, and the major AA genotype was identified as the risk factor for CHD (10). Tokat et al. (14) showed that the frequencies of the AA genotype and A allele were statistically higher in patients with breast cancer $(p<0.05)$. They suggested that the A allele may be associated with the risk of breast cancer by affecting leukocyte diapedesis. Opposite to the results by Tokat et al. (14), Fu et al. (15) found that the frequencies of the AA genotype and A allele were lower in sporadic infiltrative duct breast cancer $(p<0.0001)$. Moreover, the heterozygote AG genotype was observed to be higher $(p<0.0001)$. On the other hand, Park et al. (16) did not find a statistical difference between Behçet's disease and controls for rs8058823. Similarly to the results by Park et al. (16), we did not observe a statistically difference between the tumor and healthy kidney tissues. However, other studies obtained genomic DNA from the blood, while in our study, somatic DNA from the tumor and healthy kidney tissue was used. In addition, since the current studies in the literature included different diseases or different races, this may explain why our results are different from other studies. The limitations to our study are the small number of samples and the lack of clinical data of patients and the analysis of genes and proteins.

\section{CONCLUSION}

To the best of our knowledge, this is the first study showing JAM-A rs790056 and LFA-1 rs8058823 in kidney cancer tissues. We did not find any relation between these variation and kidney cancer.

Ethics Committee Approval: Ethics committee approval was received for this study from the Ethics Committee of Clinical Research of Istanbul University School of Medicine (Number: 2016/535).

Informed Consent: Informed consent was obtained from the patients who participated in this study.

Peer-review: Externally peer-reviewed.

Author Contributions: Concept - H.H.P., B.Ç., S.P., B.T., A.Ö.; Design - H.H.P., B.Ç., S.P., B.T., A.Ö.; Supervision - H.H.P., B.Ç., S.P., B.T., A.Ö.; Resources H.H.P., B.Ç., S.P., B.T., A.Ö.; Data Collection and/or Processing - H.H.P., B.Ç., S.P., B.T., A.Ö.; Analysis and/or Interpretation - H.H.P., B.Ç., S.P., B.T., A.Ö.; Literature Search - H.H.P., B.Ç., S.P., B.T., A.Ö.; Writing Manuscript - H.H.P., B.Ç., S.P., B.T., A.Ö.; Critical Review - H.H.P., B.Ç., S.P., B.T., A.Ö.

Conflict of Interest: The authors have no conflict of interest to declare.

Financial Disclosure: The authors declared that this study has received no financial support. 


\section{REFERENCES}

1. Linehan WM, Srinivasan R, Schmidt LS. The genetic basis of kidney cancer: a metabolic disease. Nat Rev Urol 2010; 7: 277-85. [CrossRef]

2. Tahbaz R, Schmid M, Merseburger AS. Prevention of kidney cancer incidence and recurrence: lifestyle, medication and nutrition. Curr Opin Urol 2018; 28: 62-79. [CrossRef]

3. Gutwein P, Schramme A, Voss B, Abdel-Bakky MS, Doberstein K, Ludwig $A$, et al. Downregulation of junctional adhesion molecule-A is involved in the progression of clear cell renal cell carcinoma. Biochem Biophys Res Commun 2009; 380: 387-91. [CrossRef]

4. Pong WW, Walker J, Wylie T, Magrini V, Luo J, Emnett RJ, et al. F11R is a novel monocyte prognostic biomarker for malignant glioma. PLoS One 2013; 8: doi: 10.1371/journal.pone.0077571. [CrossRef]

5. Solimando AG, Brandl A, Mattenheimer K, Graf C, Ritz M, Ruckdeschel $A$, et al. JAM-A as a prognostic factor and new therapeutic target in multiple myeloma. Leukemia 2018; 32: 736-43. [CrossRef]

6. Hwang I, An BS, Yang H, Kang HS, Jung EM, Jeung EB. Tissue-specific expression of occludin, zona occludens-1, and junction adhesion molecule $A$ in the duodenum, ileum, colon, kidney, liver, lung, brain, and skeletal muscle of C57BL mice. J Physiol Pharmacol 2013; 64: 11-8.

7. Ostermann G, Weber KS, Zernecke A, Schröder A, Weber C. JAM-1 is a ligand of the beta(2) integrin LFA-1 involved in transendothelial migration of leukocytes. Nat Immunol 2002; 3: 151-8. [CrossRef]

8. Song E, Song W, Ren M, Xing L, Ni W, Li Y, et al. Identification of potential crucial genes associated with carcinogenesis of clear cell renal cell carcinoma. J Cell Biochem 2018; 119: 5163-74. [CrossRef]
9. Boguslawska J, Kedzierska H, Poplawski P, Rybicka B, Tanski Z, Piekielko-Witkowska A. Expression of Genes Involved in Cellular Adhesion and Extracellular Matrix Remodeling Correlates with Poor Survival of Patients with Renal Cancer. J Urol 2016; 195: 1892-902. [CrossRef]

10. Tokat B, Kurt O, Bugra Z, Ozturk O, Yilmaz-Aydogan H. Investigation of the monocyte diapedesis-related LFA-1 and JAM-A gene variants in Turkish coronary heart disease patients. Meta Gene 2013; 2: 1-10. [CrossRef]

11. Zhao C, Lu F, Chen H, Zhao X, Sun J, Chen H. Dysregulation of JAMA plays an important role in human tumor progression. Int J Clin Exp Pathol 2014; 7: 7242-8.

12. Zhang M, Luo W, Huang B, Liu Z, Sun L, Zhang Q, et al. Overexpression of JAM-A in non-small cell lung cancer correlates with tumor progression. PLoS One 2013; 8: doi: 10.1371/journal.pone.0079173. [CrossRef]

13. Tomita $Y$, Nishiyama T, Watanabe H, Fujiwara M, Sato S. Expression of intercellular adhesion molecule-1 (ICAM-1) on renal-cell cancer: possible significance in host immune responses. Int J Cancer 1990; 46: 1001-6. [CrossRef]

14. Tokat B, Öztürk T, Seyhan MF, Calay $Z$, Ilvan S, Tüzüner MB, et al. Interactive Effects of Common Haplotypes of Two Leukocyte Diapedesis-Related Genes, LFA-1 and JAM-A on Breast Cancer Risk. Int J Hematol 2018; 1: 45-52. [CrossRef]

15. Fu Z, Jiao M, Zhang M, Xu F, Yuan W, Pang D, et al. LFA-1 gene polymorphisms are associated with the sporadic infiltrative duct breast carcinoma in Chinese Han women of Heilongjiang Province. Breast Cancer Res Treat 2011; 127: 265-71. [CrossRef]

16. Park SR, Park KS, Park YJ, Bang D, Lee ES. CD11a, CD11c, and CD18 gene polymorphisms and susceptibility to Behçet's disease in Koreans. Tissue Antigens 2014; 84: 398-404. [CrossRef] 